\title{
Covid-19 Maneuver on Socio-economic: Exploitation Using Correlation
}

\section{Juliansyah Roy ${ }^{1 *}$, Zamruddin Hasid ${ }^{1}$, Diana Lestari ${ }^{1}$, Dio Caisar Darma ${ }^{2}$, Erwin Kurniawan $\mathbf{A}^{1}$}

${ }^{1}$ Faculty of Economics and Business, University of Mulawarman, Indonesia

${ }^{2}$ Department of Management, Sekolah Tinggi Ilmu Ekonomi Samarinda, Indonesia

Article Info
Article history:
Received: 13 September 2021;
Accepted: 20 October 2021;
Published: 24 October 2021.

Keywords:

Socio-economic; Covid-19;

Correlation; Cross-section;

East Kalimantan.

\begin{abstract}
Apart from the health aspect, Covid-19 has also had socio-economic effects from the fragile balance of development that has designed so far. Instantly, humans experience suffering that is difficult to predict when it will stop. The primary aim of this study is to evaluate the fragility of the socio-economic order because of Covid-19. These two motifs are the basic essence of human beings, especially the population in Indonesia. A two-way correlation applied to the IBM SPSS to predict the effect of Covid-19 on poverty, natality, minimum wages, divorce, GRDP per capita, unemployment, and crime over two periods. The database is as cross-section covering ten areas in East Kalimantan Province. We found the importance of the correlation parameter in this study that it turns out that Covid-19 closely related to the minimum wage, unemployment, and crime. Because Covid-19 has a positive effect on these three variables and the probability has met the criteria, this is also the right instrument for the government in determining special strategies. The implications of the research are to contribute to long-term management in disaster mitigation planning.
\end{abstract}

\begin{abstract}
Abstrak
Di luar aspek kesehatan, Covid-19 juga berimbas pada sosial-ekonomi dari rapuhnya keseimbangan pembangunan yang selama ini telah dirancang. Seketika, manusia mengalami penderitaan yang sulit diprediksi kapan berhentinya. Tujuan utama dari penelitian ini adalah untuk mengevaluasi rapuhnya tatanan sosial-ekonomi akibat Covid-19. Kedua motif ini sebagai hakikat dasar manusia, khususnya penduduk di Indonesia. Korelasi dua arah diaplikasikan kedalam IBM SPSS untuk memprediksi pengaruh Covid-19 terhadap kemiskinan, natalitas, upah minimum, perceraian, PDRB per kapita, pengangguran, dan kriminalitas selama dua periode. Basis data berbentuk data panel yang menjangkau sepuluh area di Provinsi Kalimantan Timur. Kami menemukan pentingnya parameter korelasi di penelitian ini bahwa ternyata Covid-19 berkaitan erat dengan upah minimum, pengangguran, dan kriminalitas. Karena Covid-19 berpengaruh positif terhadap ketiga variabel tersebut dan probabilitas telah memenuhi kriteria, maka ini juga menjadi instrumen yang tepat untuk pemerintah dalam menentukan strategi khusus. Implikasi penelitian memberikan kontribusi untuk penanganan jangka panjang dalam perencanaan mitigasi bencana.

\section{How to Cite:}

Roy, J., Hasid, Z., Lestari, D., Darma, D. C., \& Kurniawan A, E. (2021). Covid-19 Maneuver on Socio-Economic: Exploitation Using Correlation.. Jurnal Pendidikan Ekonomi \& Bisnis, 9(2), 146-162. https://doi.org/10.21009/JPEB.009.2.6
\end{abstract}

* Corresponding Author. juliansyah.roy@feb.unmul.ac.id. Juliansyah Roy 


\section{INTRODUCTION}

There is no positive meaning from the emergence of Covid-19. As a result, this epidemic has a negative effect on individual welfare, the existence of businesses of various groups, the smooth running of the economy in a country, especially the health aspect (Yijo et al., 2021). The consequences in its distribution also have a systematic effect on the consistency of human social mobility. Although interactions between individuals and other individuals change, human beings are essentially social beings and cannot separate from the connected customs, culture, and pluralism (Brata, 2021).

There are two basic differences in the impact of epidemics and epidemics based on different aspects of human life. We illustrate this from the perspective of history and the present. Likewise, Covid-19 has shown to show variability with world conditions in various regions. For example, Rahman et al. (2021) examine differences in socio-economic status (SES) as the impact of Covid-19 on households. As a result, households with low SES depend on income from government help and agricultural land. The vulnerability of economic shocks to the availability of jobs, over time, also has a negative effect on poverty and household resilience.

In the livestock sector, the spread of Covid-19 has had an expansive socio-economic impact, especially on the sustainability of the logistics system to distribute food to the community. News that highlights the huge price disparity between regions, sharp declines in production and consumption, reduction in labor, and extreme movements so that the flow of food availability experiences uncertainty (Surni et al., 2020). At the national level, imported products blocked, so that it is very limited to supply food to the community. The price disparity between regions is widening and the purchasing power is decreasing. Keep in mind, if deflation occurs, there will be mass layoffs of workers by companies.

They strongly felt the picture of the difficult situation in the mobility in the socio-economic sector. The multidimensional crisis reduces people's welfare from the limitation of socio-economic activities. Prawoto et al. (2020) analyzed the relationship of those who died and exposed to Covid19 under socio-economic conditions. The surprising findings have proven that there is a large correlation between the two relationships, where the current reality felt in Indonesia.

The meaning behind this, of course, implies how crucial it is at the national level and what about regional scales such as Kutai Kartanegara? In actual comparison, we prove that 201 cases of those exposed to Covid-19 found, including 4.27 million victims or $0.021 \%$ globally as of 30 July 2021. In fact, of these figures, the USA still held the largest, and for Indonesia it occupies the 14th position (after Germany). This means there are 623,707 recent cases or an average of 7 days or 1 week, killing up to 571,418. Most recently, until August 6, 2021, the total number of people who died in Indonesia was around 104,000 out of 3.61 million cases. What worries me is the province's coverage. For the number of cases, DKI Jakarta holds the highest record compared to the others, namely $22.9 \%$ of cases.

If we compare referring to the map of the distribution of cases per province in 2021, East Kalimantan, with a population of $1.39 \%$ of the $270,203.9$ thousand population of Indonesia, is in the top five. Therefore, it is tragic that East Kalimantan Province contributes $3.5 \%$ of the number of cases on a national scale. In fact, based on ten areas in East Kalimantan, in the 'suspects' indicator, Kutai Kartanegara is the area with the 2nd highest contribution (after Samarinda) namely 49,527 cases against East Kalimantan's figure of 394,509 cases as of 7 August 2021. Launching data released by BPS (2021), on the same day, the number of victims who died by Covid-19 was 535 people against the provincial figure of 3,886 people. This is not encouraging, because Kutai Kartanegara Regency is the area with the 3rd largest mortality rate, where for the record high and the second position is still in Balikpapan and Samarinda. The geographical aspect that is close to these three regions has made the spread of the epidemic unstoppable. Because humans are social creatures by nature, of course, economic activity and mobility in a short time make the movement of the virus faster too.

Social change theory and social mobility theory are very relevant to unexpected situations or major disasters, such as Covid-19 (Wang \& Taylor, 2016). This pandemic has disrupted intragenerational and long-term social mobility opportunities around the world. These unpredictable 
changes undermine almost every aspect of family life and social fabrics, weakening social safety nets that are detrimental to public health, economic conditions, job shocks, consumption levels, and social interactions (Day \& Fiske, 2017). Rufat et al. (2019) and Zarghami \& Dumrak (2021) review models of social vulnerability from emerging natural disasters. There is a very prominent evolution of social vulnerability and it has grown to visualize socio-economic and demographic changes.

The extent of the connection of Covid-19 to socio-economic components such as (poverty, natality, minimum wage, divorce, GRDP per capita, unemployment, and crime limits this research). With a measured theoretical and empirical review, we propose the following seven hypotheses.

Josephson et al. (2021) documented the socio-economic impact of Covid-19 on low-income countries. Governments are facing complex challenges and mutually reinforcing health systems through the availability of vaccines. The lack of general insight of individuals and households about government policies actually strengthens the perception of not using vaccines. The transmission of the virus cannot suppressed. Dimensions such as low education, close the ability to access basic needs are also low and have the potential to lose income. Limited knowledge about disease, exacerbated by the ability to get basic food and medicine disproportionately, so that prevention to reduce poverty hampered.

Even in Oman, this virus causes 15\% of deaths. Although his death not classified, Covid-19 actually worsened the respiratory tract and the transmission rate was so fast. Al-Habi et al. (2021) combining the two appropriate approaches through the coordination of holistic and health services, predicted to reduce the crisis.

The birth rate in Indonesia has increased during the Covid-19 pandemic. Supporting factors such as the government's scenario of implementing social restrictions, so that families have more time to be together. Access to health services is difficult to reach, many couples tend not to dare to visit health services for fear of being exposed to Covid-19. Of course, they do not get adequate contraception, high sexual activity, and high pregnancy rates because they not planned (Fuadi \& Irdalisa, 2020). The risk of giving birth to a baby to contract the deadly virus is also great considering that the hospital currently dominated by Covid-19 patients. By staying at home a lot, their fertility increased and gave rise to new terms such as 'baby boom' (De Rose et al., 2021).

H1(a): Covid-19 has a negative effect on natality.

The Manning \& Payne (2021) investigation comparing marriage and divorce before the pandemic and during the pandemic. They calculated the monthly marriage and divorce scale for 2018-2019 and the emergence of Covid-19 in 2020 to date with objectivity in five states in the USA. It is interesting to note that there has been a decline in the number of marriages since the pandemic hit in early 2020 because of the practice of restricting mass gatherings. Even though it is now increasing, the health protocols are still being followed. There is a shortage of divorce because most of the population carries out their daily activities at home and tends often gather with family members at home, which has implications for household harmony.

Still, in similar countries, Covid-19 procedures have a powerful effect on all families, but they are considering divorce or arranging a divorce. This special meaning gives hope to families in need of therapists through the support of other families and partners involved in certain programs during Covid-19 in the USA (Lebow, 2020).

\section{H1(b): Covid-19 has a negative effect on divorce.}

Covid-19 has had a tremendous impact on crime in the USA. Work investigating the temporal and spatial patterns of crime through crime analysis such as in the City of Chicago. Yang et al. (2021) detect crime events, distribution, and seasons in trends in the fraud, theft, and assault components from 2016 to 2019. The highest crime peak occurred in May 2020, which reported crimes by vandalizing public facilities, robbery, sexual harassment, racism, and breaking into ATMs in several locations. Vulnerability of crime on this mikto scale as a change from local groups in the city center. Crime rates have changed significantly since the emergence of Covid-19.

The new phase of controlling Covid-19 with restrictions on staying at home has caused sudden changes and affects crime in urban areas. The intensity of crime in 27 cities from 23 countries in Asia, the Middle East, and the USA was analyzed by Nivette et al. (2021). Assessment 
of the impact of social distancing by staying at home raises recent problems such as crime. There has been a drastic reduction in urban crime against those who have predominantly stayed at home during Covid-19. The lack of movement in public spaces, more stringently, reduces the large crime rate.

\section{H1(c): Covid-19 has a positive effect on crime.}

In India, the government expects a shock from unemployment through social restrictions, so companies reduce workforce to control the spread of Covid-19. In essential industries, those who hold central positions continue to work in the office (WFO) as usual. However, workers in nonessential sectors prioritized to work from home (WFH). An in-depth analysis of shocks in the supply of labor under lockdown based on industry level and employment status causes them to lose their monthly wages, especially from permanent workers, casual workers (laborers), and workers with fixed salaries (Estupinan et al., 2020). The shocks in the supply of labor are increasing, because industrial factories lay many of them off because the demand for goods has decreased in line with the low purchasing power of the people.

Historically, Covid-19 has had a significant impact on economic inequality. In Spain, over it measured three million people for economic inequality with high frequency. Aspachs et al. (2021) find facts highlighting that inequality will increase by almost $30 \%$ of the Spanish population. In just one month, the government intervened with those who experienced wage cuts, low incomes, and lost their jobs. The existence of this special application, at least reduces inequality, although it is less effective for the productive age population. Benefits for furloughed workers and extended unemployment insurance provide insight into public policy efforts. Changes in comparison need to be refined with effective instruments, even though they are short term in nature.

\section{H1(d): Covid-19 has a positive effect on the minimum wage.}

Covid-19 hit GDP again in countries that are part of the OECD. It relegated convergence theory for the 4th quarter of 2017) to the 3rd quarter of 2020. Martinho (2021) informed that at the end of 2019, new challenges in the future will change the OECD countries. The European Union has designed instruments to promote balanced development, in particular those who are socioeconomically affected.

The trend of family harmony after Covid-19 has caused a decrease in household income. Each family has a different role, condition, and background. Since Covid-19 struck, the intensity of family quarrels has increased, parents have a double burden at home, and have difficulty managing finances. Implementing quarantine at home for a long time requires adaptation that is difficult for some groups to overcome. In Indonesia, family harmony, especially those who are WFH and have been laid off from work, is psychologically affected by this unexpected situation (Afifah, 2021).

\section{H1(e): Covid-19 has a positive effect on GRDP per capita.}

In developing and developed countries, unemployment remains a problem that affects their economy and finances in the aggregate. Ahmad et al. (2020) pays attention to the impact of Covid19 on unemployment in selected countries such as Italy, Turkey, Spain, Germany, France, and Belgium. Major findings summarize that in the coming years, the unemployment rate will be higher than it is now. Because of Covid-19, at least in these six countries, it took five years to overcome the socio-economic impact.

In five European countries (UK, Italy, Spain, Germany and France), during the period December 2019-December 2020, there was a significant transformation in unemployment. This is because of the ongoing Covid-19 cases (Su et al., 2021). Future policies provide guidance for the labor market that is needed immediately. The effect is still small because the quantity of labor from the five countries is relatively small compared to outside Europe.

The economic downturn is not the only failure of Covid-19, but it also extends to health losses and social injustices such as unemployment (Nghiem \& Wilson, 2021). The high cost of health care to reduce the burden of unemployment, as the government takes special consideration in several high-income countries through additional job creation programs in minimizing the risk of unemployment. 


\section{H1(f): Covid-19 has a positive effect on unemployment.}

The presence of Covid-19, which seems to have not disappeared, threatens the population in terms of death. The connection between Covid-19 and poverty depends on the availability of vaccines in poor countries with overcapacity populations (Finch \& Finch, 2020). This is in contrast to those living in more affluent countries and less populated in metropolitan areas, such as Washington (Lee et al., 2011). Low income and lack of resources triggers dominant poverty, so that poor communities are powerless.

In the worst-case scenario, Suryahadi et al. (2020) conclude that tens of millions of more people will be poor. Substantially, Indonesia's economic progress does not seem to have reduced poverty. Covid-19 in Indonesia has expanded its reach to disrupt the socio-economic sector even though the government has prepared a protection program to help the poor, but it will take a long time.

H1(g): Covid-19 has a positive effect on poverty.

Table 1. Covid-19 Convergence and Socio-Economic Dimensions

\begin{tabular}{|c|c|c|c|c|c|c|c|}
\hline Author(s) & Poverty & Natality & $\begin{array}{l}\text { Minimum } \\
\text { wage }\end{array}$ & Divorce & $\begin{array}{l}\text { GDRP } \\
\text { per } \\
\text { capita }\end{array}$ & $\begin{array}{l}\text { Unem- } \\
\text { ployment }\end{array}$ & Crime \\
\hline $\begin{array}{l}\text { Finch \& Finch } \\
(2020)\end{array}$ & $\sqrt{ }$ & $\sqrt{ }$ & - & - & - & - & - \\
\hline Lee et al (2011) & $\sqrt{ }$ & - & - & - & - & - & - \\
\hline $\begin{array}{l}\text { Suryahadi et al. } \\
(2020)\end{array}$ & $\sqrt{ }$ & - & - & - & $\sqrt{ }$ & - & - \\
\hline $\begin{array}{l}\text { Josephson et al. } \\
\text { (2021) }\end{array}$ & - & - & - & - & $\sqrt{ }$ & - & - \\
\hline $\begin{array}{l}\text { Al Wahaibi et } \\
\text { al. (2021) }\end{array}$ & - & $\sqrt{ }$ & - & - & - & - & - \\
\hline $\begin{array}{l}\text { Fuadi \& Irdalisa } \\
(2020)\end{array}$ & - & $\sqrt{ }$ & - & - & - & - & - \\
\hline $\begin{array}{l}\text { De Rose et al. } \\
\text { (2021) }\end{array}$ & - & $\sqrt{ }$ & - & - & $\sqrt{ }$ & $\sqrt{ }$ & - \\
\hline $\begin{array}{l}\text { Estupinan et al. } \\
(2020)\end{array}$ & - & - & $\sqrt{ }$ & - & - & $\sqrt{ }$ & - \\
\hline $\begin{array}{l}\text { Aspachs et al. } \\
\text { (2021) }\end{array}$ & - & - & $\sqrt{ }$ & - & - & $\sqrt{ }$ & - \\
\hline $\begin{array}{l}\text { Manning \& } \\
\text { Payne (2021) }\end{array}$ & - & - & - & $\sqrt{ }$ & - & - & - \\
\hline Lebow (2020) & - & - & - & $\sqrt{ }$ & - & $\sqrt{ }$ & - \\
\hline Martinho (2021) & - & - & - & - & $\sqrt{ }$ & - & - \\
\hline Afifah (2021) & - & - & - & $\sqrt{ }$ & - & $\sqrt{ }$ & - \\
\hline $\begin{array}{l}\text { Ahmad et al. } \\
(2020)\end{array}$ & - & - & $\sqrt{ }$ & - & - & $\sqrt{ }$ & - \\
\hline Su et al. (2021) & - & - & - & - & - & $\sqrt{ }$ & - \\
\hline $\begin{array}{l}\text { Nghiem \& } \\
\text { Wilson (2021) }\end{array}$ & - & $\sqrt{ }$ & - & - & - & $\sqrt{ }$ & - \\
\hline $\begin{array}{l}\text { Yang et al. } \\
(2021)\end{array}$ & - & - & - & - & - & - & $\sqrt{ }$ \\
\hline $\begin{array}{l}\text { Nivette et al. } \\
(2021)\end{array}$ & $\sqrt{ }$ & - & - & - & - & - & $\sqrt{ }$ \\
\hline
\end{tabular}

Source: various study groups

Table 1 summarizes the relevance of the empirical findings at the regional, national, and global levels that underlie the needs of this research. The diversity of previous studies has the advantage that it describes the impact of Covid-19 on two social problems (natality, divorce, and crime) and economic problems (minimum wages, GRDP per capita, unemployment, and poverty). 
The reaction to socio-economic mobility needs to investigate, given its very broad contribution to the development of the topic. Covid-19 has had a major impact, so the urgency in this study is to provide valuable experiences and contributions related to the objects that have designed. We review the relevance of this research in stages. Introduction in the first session, an overview of the current conditions regarding Covid-19 in Indonesia and East Kalimantan, conceptual design in the second session, methods and data sources in the third session, the results of the analysis and discussion in the fourth session, and conclusions in the fifth session.

\section{METHOD}

The research scheme concentrates on the quantitative form. Solving research objectives to answer hypotheses, where statistical results supported by IBM SPSS (Azhari et al., 2020; Mardisetosa et al., 2020). We collected cross-section through trusted sources, such as publications from the government of East Kalimantan Province (in this case, BPS and the Department of Communication and Information).

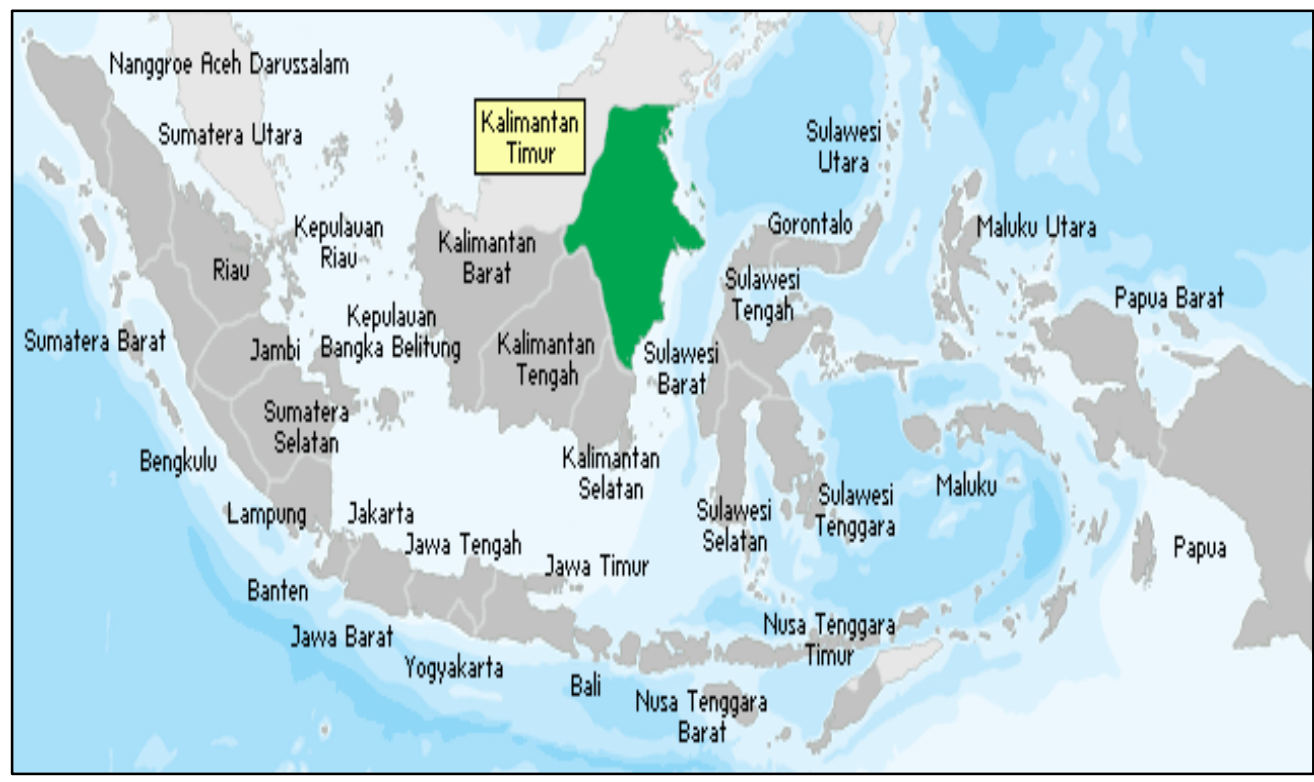

Source: Japan Official Development Assistance (2021)

Figure 1. Focus of Research Area

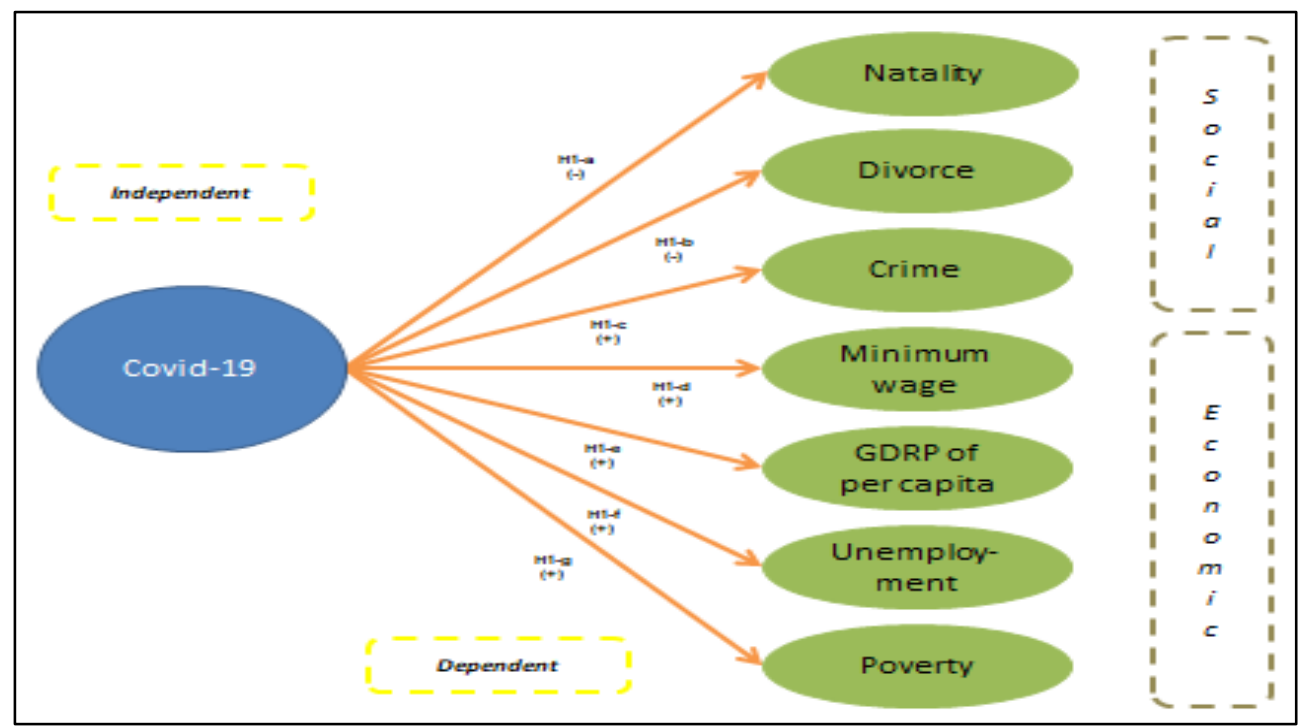

Figure 2. Relationship Expectations on Model 
This data is only limited to the 2020-2021 edition or since the emergence of Covid-19 in ten areas in East Kalimantan (see Figure 1). Correlation analysis determines whether the predicted relationship between the variables can influence each other positively or vice versa. This program applies to the effect of Covid-19 as an independent variable on the components of the dependent variables (poverty, natality, minimum wage, divorce, GRDP per capita, unemployment, and poverty). It developed the details of the variables in Figure 2.

We did planning on stages. The first part covers data collection. In the second part is validation and data processing. The third part covers the interpretation of the data. From fourth part is affirmation and conclusion (e.g. Shimamoto, 2019; Zarkasyi et al., 2021). The provision of correlation is two-way, which explains the strength and weakness of the influence based on seven hypotheses. This analytical technique is very precise in identifying linear relationships between variables. Spatial correlation suitability includes five signs, including perfect correlation, uncorrelated, weak correlation, negative correlation, and positive correlation (Suparjo et al., 2021).

\section{RESULTS AND DISCUSSION}

Table 2 displays descriptive statistics for the seven variables with different units. The Covid19 data uses a measure of the number of people who have confirmed positive for Covid-19. Soul also measured data for the rate of natality. The percentage-based poverty and unemployment data. Then, the minimum wage and GRDP per capita refer to Rupiah (IDR). Meanwhile, crime and divorce rates reviewed on a case scale.

Table 2. Descriptive Statistics $(\mathrm{n}=20)$

\begin{tabular}{lllllll}
\hline Components & Min. & Max. & Mean & Std. Dev. & Range & Std. Error \\
\hline Covid-19 & 98 & 17,360 & $4,285.65$ & $5,196.79$ & 17.262 & 0.512 \\
Poverty & 2.42 & 11.44 & 7.02 & 2.74 & 9.02 & 0.512 \\
Natality & 247 & 15,311 & $6,407.35$ & 4531.08 & 15.064 & 0.512 \\
Minimum wage & 2.787 .920 & 3.386 .593 & 3.084 .047 .60 & 172.522 .46 & 598,673 & 0.512 \\
Divorce & 2 & 392 & 117.10 & 104.41 & 390 & 0.512 \\
GDRP per capita & 40.634 .000 & 355.550 .000 & 153.876 .500 & 85.771 .980 .11 & 314.916 .000 & 0.512 \\
Unemployment & 3.49 & 9.46 & 6.034 & 1.75 & 5.97 & 0.512 \\
Crime & 5 & 1,420 & 434.85 & 364.48 & 1,415 & 0.512 \\
\hline
\end{tabular}

Source: calculation using SPSS

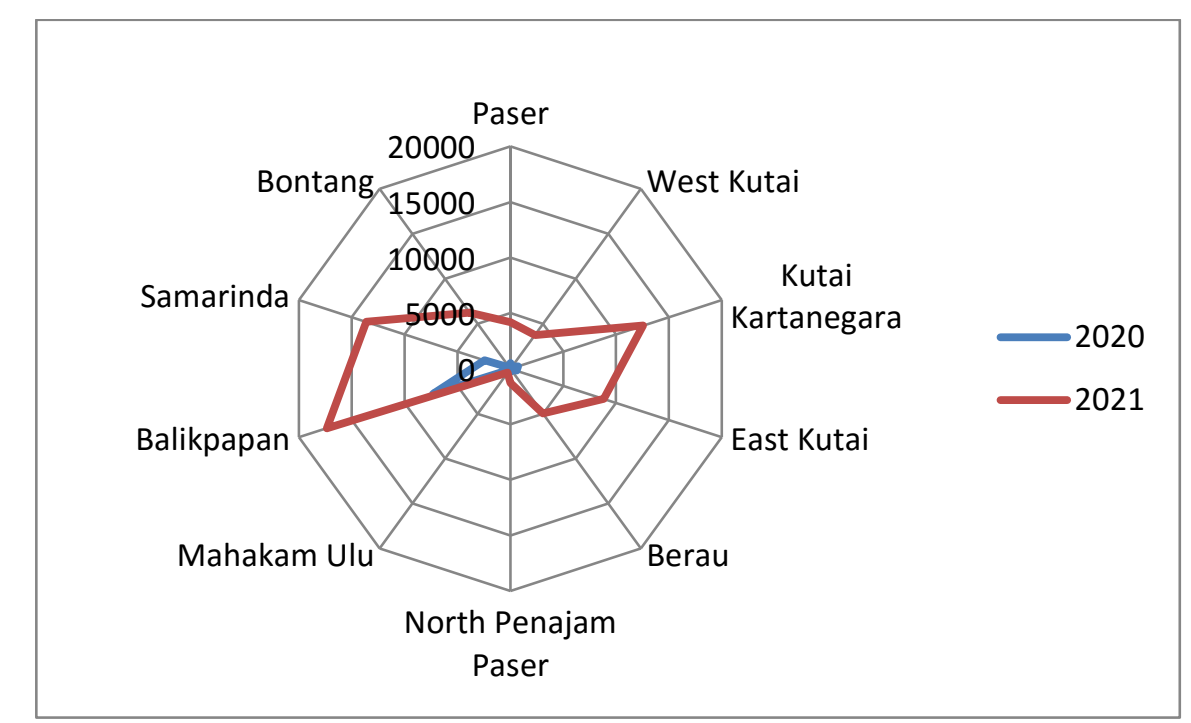

Source: Office of Communication and Information - East Kalimantan Province (2021)

Figure 3. Positive Case of Covid-19 in East Kalimantan Province as of June 2020-2021

For those who have infected with Covid-19 from June 2020 to June 2020, at the East 
Kalimantan Province level, there has been a significant increase reaching $484.62 \%$. This gain is inseparable from a spike in cases from the original 12,469 to 72,896. Ranking, Figure 3 shows that Bontang City is the highest at around $4806.30 \%$ at the same time and Balikpapan City is the area with the lowest increase for those confirmed to have exposed to Covid-19, which is $137.71 \%$. Judging from the numbers, Balikpapan City is the largest contributor to the Covid-19 index number because this area is a gateway from various outside regions and other countries to enter East Kalimantan.

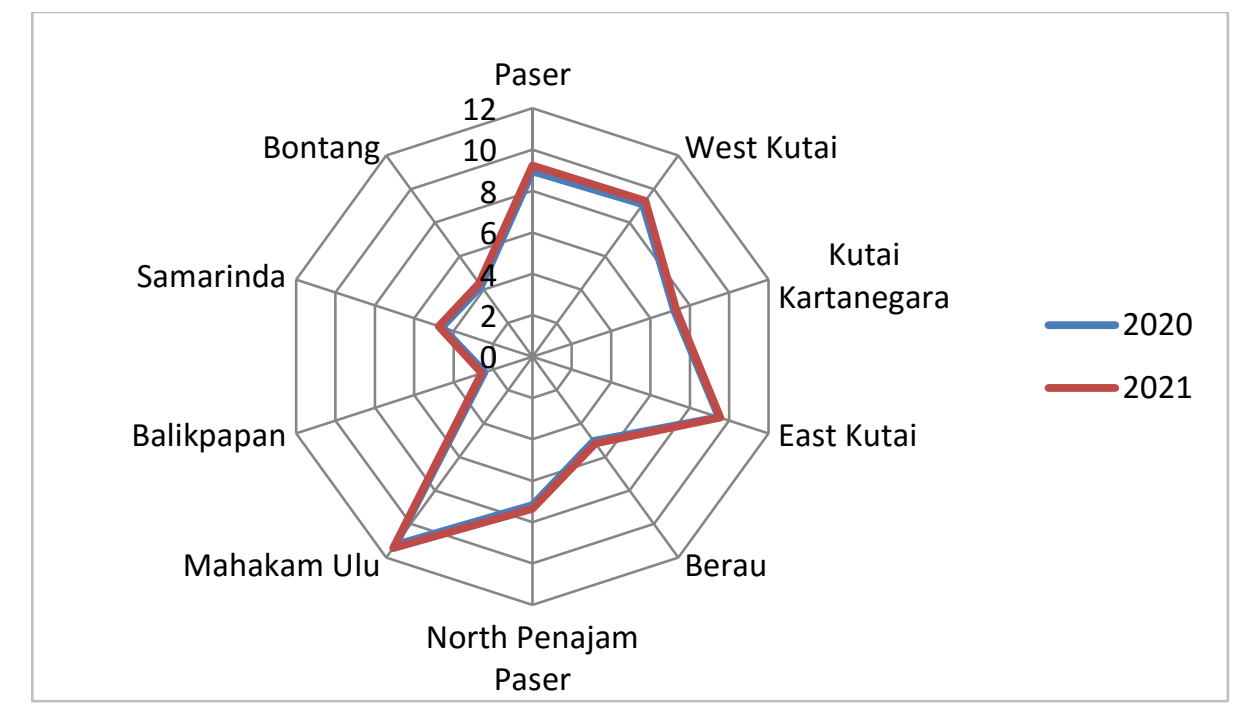

Source: BPS - East Kalimantan Province (2021)

Figure 4. Poor Population in East Kalimantan Province per March, 2020-2021

Since Covid-19 spread in Indonesia and the epicentrum was dominant on the island of Java such as Jakarta, it has now continued to the outermost areas, including East Kalimantan Province. It noted that they have also felt the effects of poverty in remote or outermost areas such as Mahakam Ulu Regency, where aggregate growth reached $1.69 \%$ with a trend from 2020 to 2021 of $11.25 \%$ and $11.44 \%$. This percentage even exceeds the achievement at the East Kalimantan level for two years (5.94\% and 6.10\%). Figure 4 also shows that Balikpapan City is actually the lowest poverty pocket because it has since focused more on addressing socio-economic problems than health, where the poverty rate is $2.42 \%$ for 2020 and in 2021 it is $2.57 \%$.

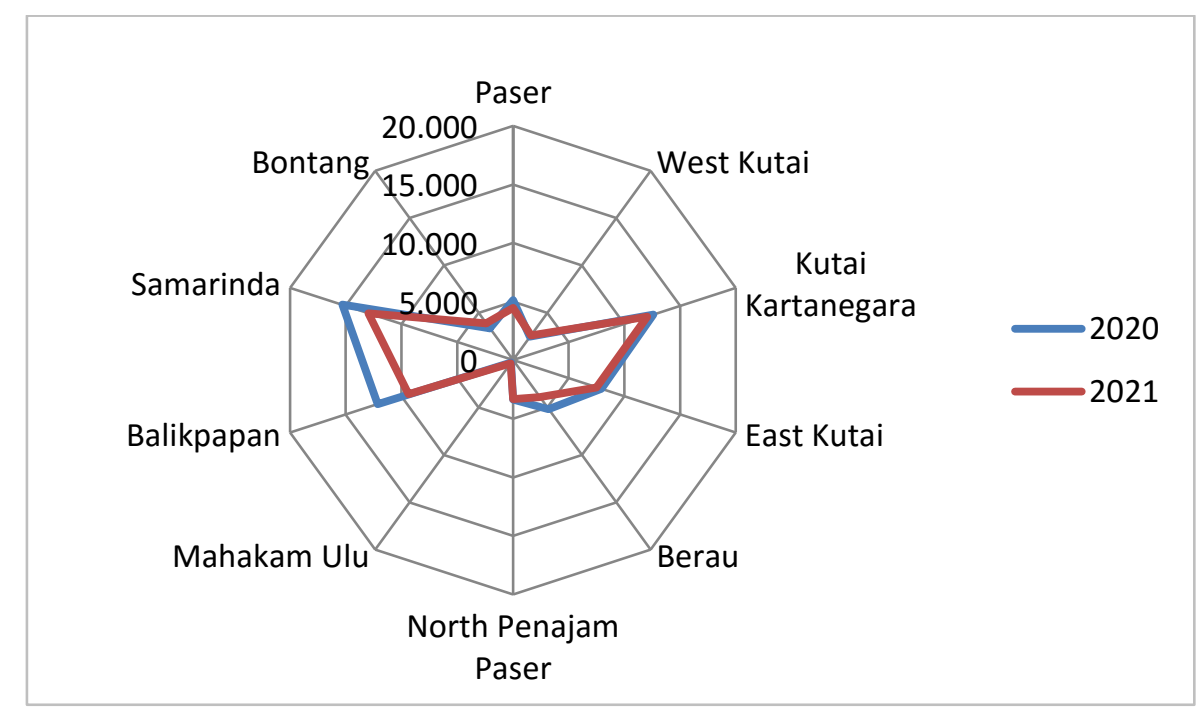

Source: BPS - East Kalimantan Province (2021)

Figure 5. Number of Babies Born Safely in East Kalimantan Province, 2020-2021

Although two big cities, such as Samarinda and Balikpapan, are the areas with the highest population density, in terms of birth rates and handling the safety of babies born, Kutai Kartanegara 
Regency is the most successful. This implies that those who work a lot from home spend more time with their families and the frequency of sex is higher, so that the number of births increases. Since Covid-19 took place, there has been a significant overall decline in East Kalimantan Province from the natality rate of $-10.87 \%$ or from 67,708 people to 60,349 people (see Figure 5 ). In fact, in areas with less population, such as Mahakam Ulu Regency, it is very reasonable if the natality rate is small compared to other areas. Mothers who infected with Covid-19, of course, endanger the baby in her womb because the birth process takes place in health facilities such as hospitals, which accommodate many Covid-19 patients. Sometimes, in fact, many mothers who infected with Covid19 can give birth to healthy babies. However, there is a risk of harming the baby if there is no sterile room.

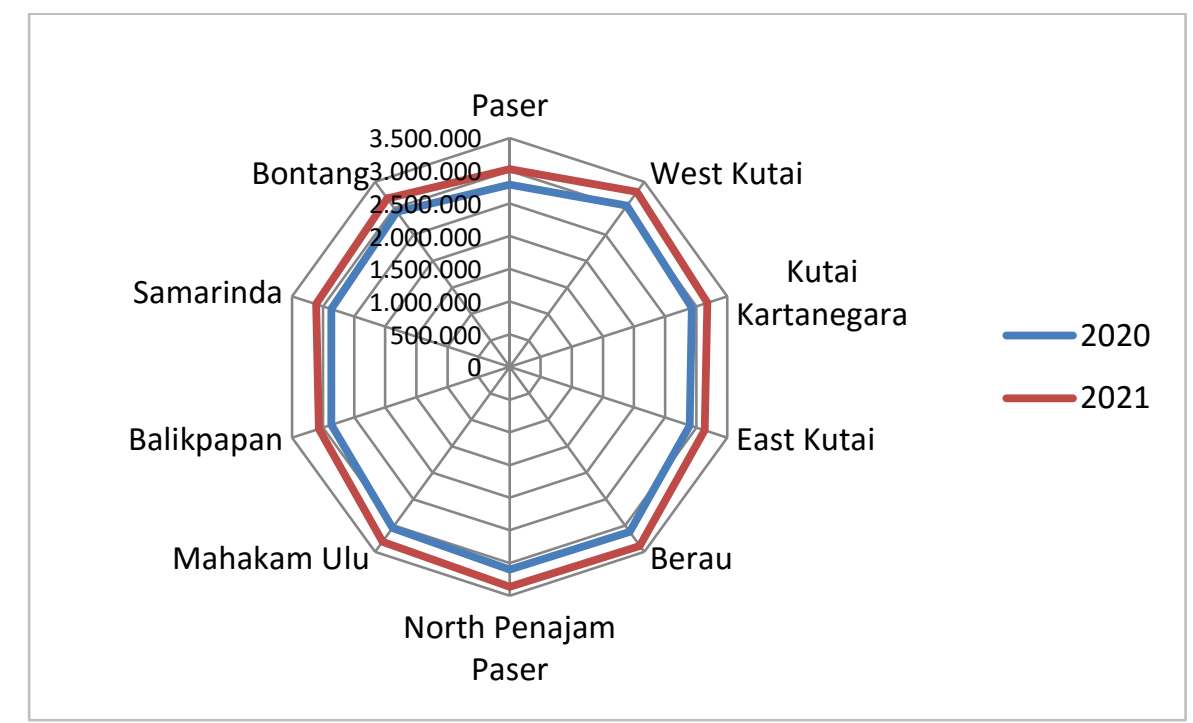

Source: BPS - East Kalimantan Province (2021)

Figure 6. Minimum Wage (UMK) of Regency/City in East Kalimantan Province, 2020-2021

Figure 6 reflects the minimum wage decided by the Governor of East Kalimantan No. 560/K.619/2020 has adjusted the conditions of purchasing power parity and the Consumer Price Index (CPI) of the local community. At the provincial level, there was a growth of $8.51 \%$ which previously was Rp. 2,747,561 in 2020, now to Rp. 2,981,379 for 2021. It also showed this diversity in Regencies/Cities. However, specifically for the City of Balikpapan, which grew by $7.02 \%$ in two periods.

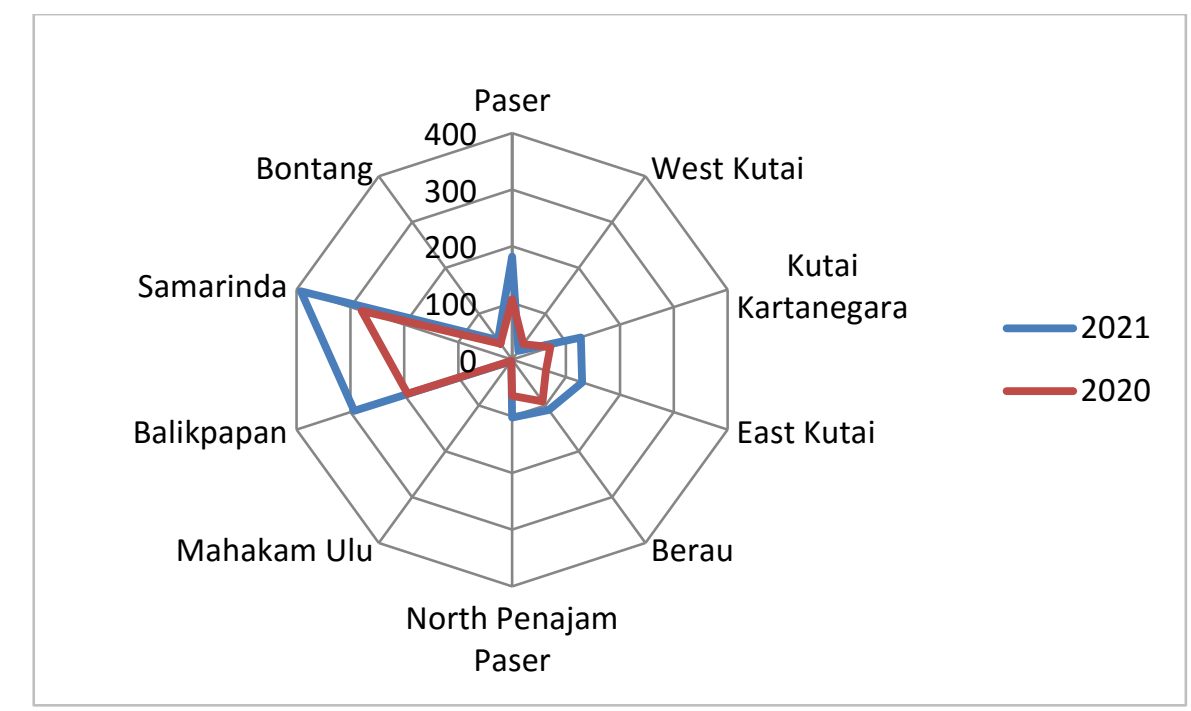

Source: BPS - East Kalimantan Province (2021)

Figure 7. Level of One Party Divorce in East Kalimantan Province, 2020-2021 
The causes of happiness in the household can disturb if the major needs, welfare, social influences, and social factors not handled properly. Workloads and lock downs frustrate people. As a result, the mind saturated and the social conflicts that are present in a family because of Covid19 are very vulnerable. This term is also close to 'burn out'. One-sided divorce cases, whether from husband or wife, are increasingly worrying. Precisely because the workload that should ideally completed at the office is now not normal and taking care of children at home. The case study in East Kalimantan, Figure 7, makes clear the sharpness regarding divorce from 20201,097 cases to 1,402 cases in 2021 . There is an increase in cases of $27.8 \%$ in two periods. In terms of quantity, Samarinda City holds the record for the largest number of divorce cases. However, in percentage terms, East Kutai Regency is the dominant one.

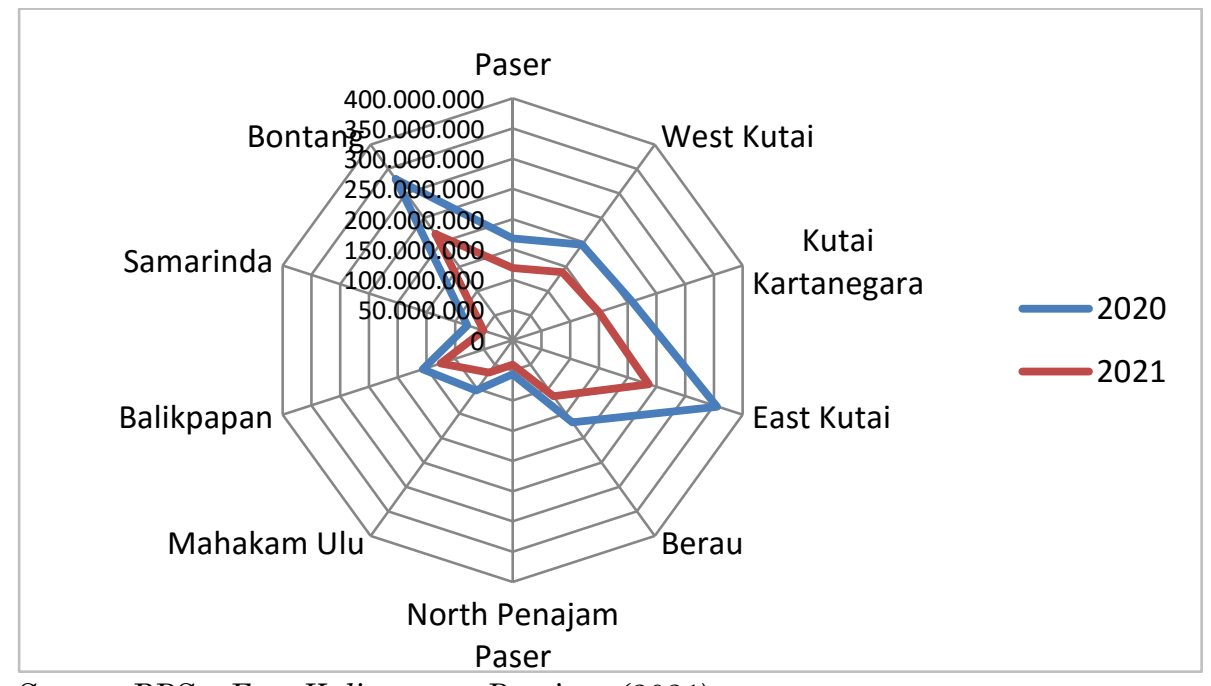

Source: BPS - East Kalimantan Province (2021)

Figure 8. GRDP per Capita on Constant Price Basis in East Kalimantan Province, 2020-2021

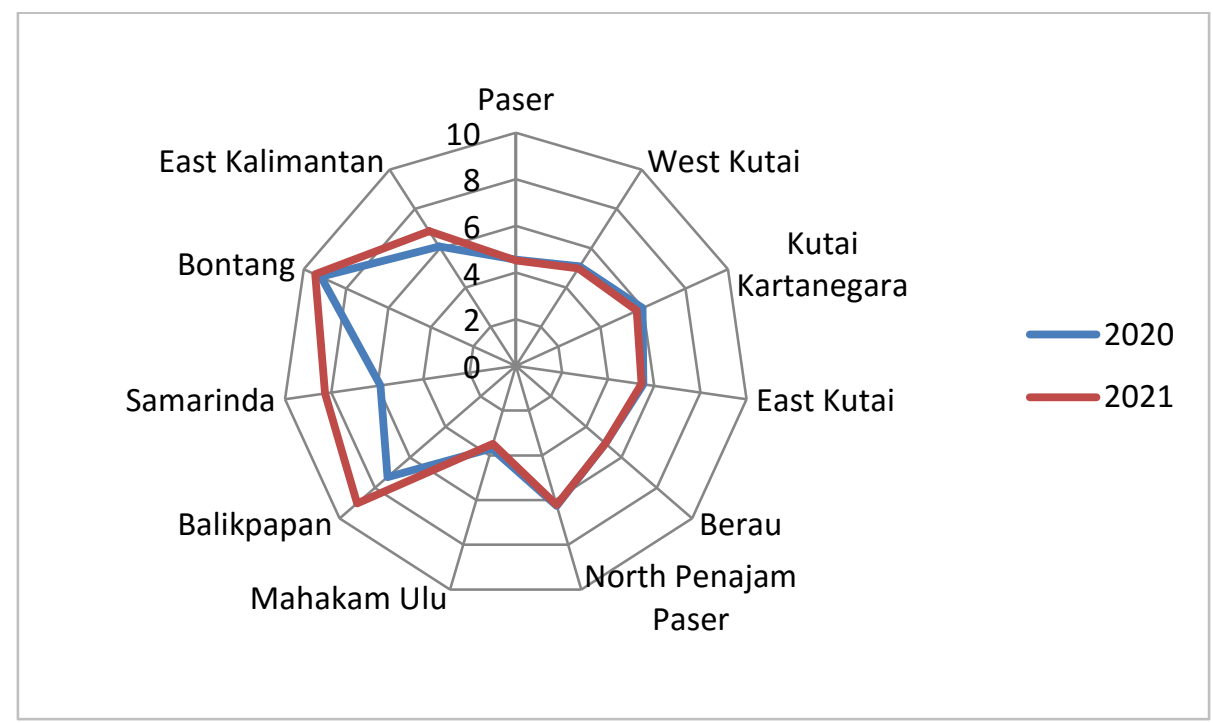

Source: BPS - East Kalimantan Province (2021)

Figure 9. Open Unemployment Rate in East Kalimantan Province, per August 2020-2021

One of the most prominent indicators in assessing whether an individual is happy is income. Despite the many indicators that measure it, the level of individual and household well-being determines their happiness. How not, the history of global pandemics from time to time shows that these factors are very vulnerable to hitting the family economy. Those who have jobs, savings, and excess capital over time will risk becoming a burden on the government. At the national level, 
besides economic growth, GRDP per capita is part of and a signal of the level of welfare of the population. Figure 8 observes the value of GRDP per capita for ten areas in East Kalimantan which has fallen drastically. It reflected the average for the level of the East Kalimantan Province alone in GRDP per capita, which is close to -31\%. Speaking in aggregate, Mahakam Ulu Regency is the area most affected by Covid-19, where the GRDP per capita is up to $-35.42 \%$. Mahakam Ulu Regency is the outermost area in East Kalimantan, which has just bloomed from West Kutai Regency since 2014. This means that this area is also difficult to reach and does not have complete access compared to other areas to get out of socio-economic problems.

Figure 9 has confirmed the open unemployment rate in East Kalimantan Province, which recorded a significant increase since Covid-19 as of August 2020 to August 2021, which accounted for $12.81 \%$. Even though Samarinda City has the largest unemployment growth at $40.72 \%$, two equally positive areas, such as Balikpapan at 23.46\% and Bontang, also followed this at 2.94\%. The rest, six regions confirmed to have unemployment problems (Paser, West Kutai, Kutai Kartanegara, East Kutai, North Penajam Paser, and Mahakam Ulu). Specifically, Mahakam Ulu has the highest unemployment rate. Berau is the only area with constant unemployment growth. In two periods, both in 2020 and 2021, the unemployment rate in Berau Regency is quite stable at 5.08\%.

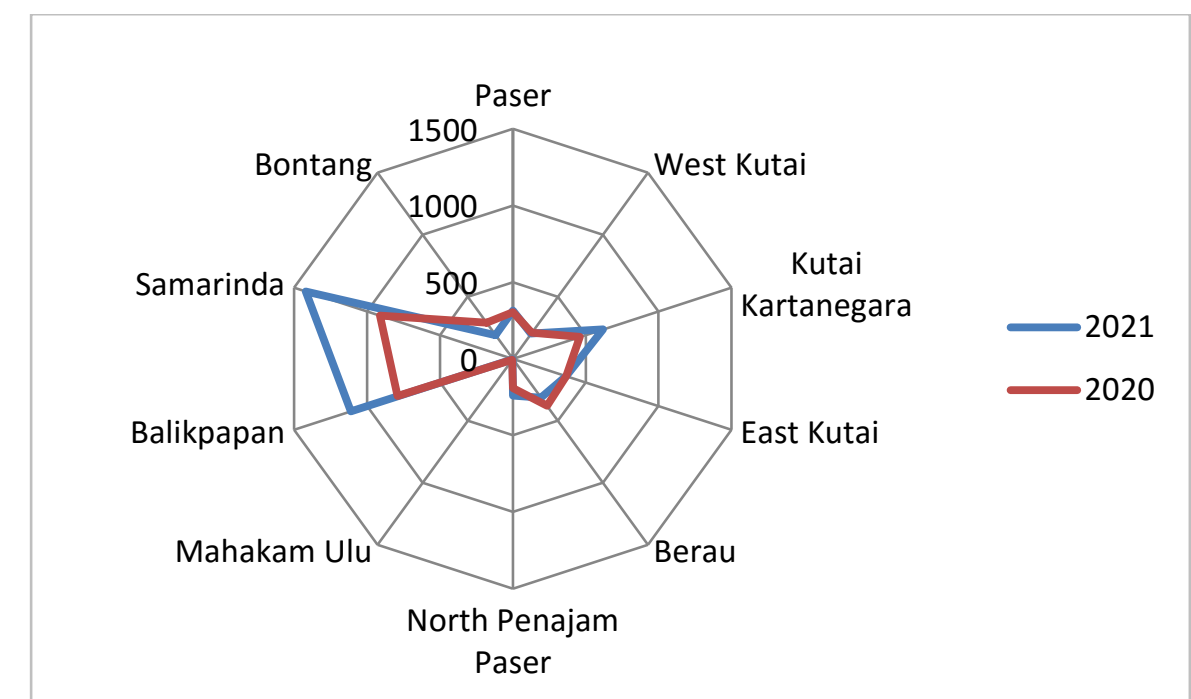

Source: BPS - East Kalimantan Province (2021)

Figure 10. The Intensity of the Crime Reported in East Kalimantan Province, 2020-2021

Crime is the second part of a vicious circle after unemployment. Anser et al. (2020) describe a criminal trap that is unavoidable because of uneven economic growth, so that it continues to the rate of poverty which has the potential to increase inequality between the weak and those who classified as rich. These are the pitfalls to watch out for. The East Kalimantan Provincial Government can actually prevent it through a strict distribution and allocation function for residents who do not have permanent jobs, have lower incomes, and classified as poverty line. However, because the government has a limited budget to subsidize them because it also concentrates on Covid-19, then everything divided. The phenomenon of crime in East Kalimantan Province increases from 2020 to 2021 , reaching $22.26 \%$ of criminal cases detected by the police. The crime rate in question is very varied, including drugs, murder, sexual crimes, theft, fraud, and forgery. Noted, there are $55.87 \%$ cases in Samarinda that have reported. The city of Samarinda is the most vulnerable area among the others, considering that Samarinda is the center of government and the capital city of East Kalimantan. Of the six types of cases, only Bontang City is the safest because they prove that the crime rate has decreased by $-34.71 \%$ in two periods.

The two-way correlation in the first structure, linking Covid-19 with poverty, is negative, where if there is an increase in people who confirmed to be exposed to Covid-19, it actually reduces poverty significantly $(\mathrm{p}<0.05)$. In the second structure, on natality, Covid-19 had a positive impact with a correlation of $51.4 \%$ and significant $(\mathrm{p}<0.05)$. In the third structure, Covid-19 has affected the minimum wage insignificantly, because the correlation is weak. Meanwhile, in the fourth 
structure, divorce determined by Covid-19. As a result, Covid-19 became $70 \%$ of the factors that significantly affected divorce in East Kalimantan Province $(\mathrm{p}<0.01)$. A negative and insignificant correlation occurs in the fifth structure, each addition of Covid-19 is also prone to reducing GRDP per capita by $16.6 \%$. Calculation of the correlation in the sixth structure, Covid-19 has the potential to increase unemployment significantly because it proved the correlation at $49.5 \%$ and $\mathrm{p}<0.05$. Apparently, the determination of Covid-19 has presented fresh problems such as poverty and closely related. The correlation value is up to $73.5 \%$ with a significance less than $1 \%(p<0.01)$.

Table 3. Correlation Estimation $(\mathrm{n}=20)$

\begin{tabular}{lcccccccc}
\hline Components & {$[1]$} & {$[2]$} & {$[3]$} & {$[4]$} & {$[5]$} & {$[6]$} & {$[7]$} & {$[8]$} \\
\hline Covid-19 & 1 & $-0.462^{*}$ & $0.514^{*}$ & 0.146 & $0.700^{* *}$ & -0.166 & $0.495^{*}$ & $0.735^{* *}$ \\
Poverty & & $(0.041)$ & $(0.020)$ & $(0.538)$ & $(0.001)$ & $(0.484)$ & $(0.027)$ & $(0.000)$ \\
& $-0.462^{*}$ & 1 & $-0.519^{*}$ & 0.158 & $-0.561^{*}$ & -0.004 & $-0.795^{* *}$ & $-0.647^{* *}$ \\
Natality & $(0.041)$ & & $(0.019)$ & $(0.505)$ & $(0.010)$ & $(0.987)$ & $(0.000)$ & $(0.002)$ \\
& $0.514^{*}$ & $-0.519^{*}$ & 1 & -0.441 & $0.734^{* *}$ & 0.014 & 0.345 & $0.827^{* *}$ \\
Minimum wage & $(0.020)$ & $(0.019)$ & & $(0.052)$ & $(0.000)$ & $(0.952)$ & $(0.136)$ & $(0.000)$ \\
& 0.146 & 0.158 & -0.441 & 1 & -0.211 & -0.422 & -0.132 & -0.268 \\
Divorce & $(0.538)$ & $(0.505)$ & $(0.052)$ & & $(0.371)$ & $(0.064)$ & $(0.579)$ & $(0.254)$ \\
& $0.700^{* *}$ & $-0.561^{*}$ & $0.734^{* *}$ & -0.211 & 1 & -0.344 & 0.399 & $0.939^{* *}$ \\
GDRP per capita & $(0.001)$ & $(0.010)$ & $(0.000)$ & $(0.371)$ & & $(0.137)$ & $(0.081)$ & $(0.000)$ \\
& -0.166 & -0.004 & 0.014 & -0.422 & -0.344 & 1 & 0.227 & -0.185 \\
Unemployment & $(0.484)$ & $(0.987)$ & $(0.952)$ & $(0.064)$ & $(0.137)$ & & $(0.336)$ & $(0.436)$ \\
& $0.495^{*}$ & $-0.795^{* *}$ & 0.345 & -0.132 & 0.399 & 0.227 & 1 & $0.520^{*}$ \\
Crime & $(0.027)$ & $(0.000)$ & $(0.136)$ & $(0.579)$ & $(0.081)$ & $(0.336)$ & & $(0.019)$ \\
& $0.735^{* *}$ & $-0.647^{* *}$ & $0.827^{* *}$ & -0.268 & $0.939^{* *}$ & -0.185 & $0.520^{*}$ & 1 \\
\hline
\end{tabular}

Source: calculation using SPSS (Notes: ${ }^{*}$ Correlation $<0.05,{ }^{* *}$ Correlation $\left.<0.01\right)$

Table 3 explains that the abilities of each pathway are very different and have contradicted the theory and previous studies. The accumulated results in the correlation test also conclude that the two-way probabilities at $1 \%$ and $5 \%$ have different meanings, respectively. Other implications also indicate that the increase in Covid-19 in East Kalimantan is actually an anti-climax to poverty and negative per capita GDRP. We proved that the positive effects of Covid-19 have added to natality, divorce, unemployment, minimum wage, and crime.

There was a turmoil in the community's economy because many were unemployed and some of them had the potential to enter the abyss of poverty. In addition, there is a shift in social aspects because of the prolonged Covid-19 to cause conflict if they do not fulfil their basic needs (Supriatna, 2020). The government needs to expand its reach through subsidy programs and protect the lower middle class. On the positive side, public awareness arises to help each other collectively, so that solidarity grows between them.

Closed social distancing measures, evaluated by Martin et al. (2020) of individual socioeconomic affects. Microeconomic models project that there will be major disruptions to consumption, savings, poverty and household incomes during this crisis period. On the one hand, evaluation of a macroeconomic model is more appropriate to explore the impact of Covid-19 because it also indirectly affects household decision-making from exogenous shocks and the potential effects of natural disasters (Rebhun, 2021). Expansion through simulation is at least the basis for careful considerations taken by the government on a regional scale.

The false signal reviewed by Mofijur et al. (2021) implies human suffering, turning people's lives upside down, health plummeting, and the economic downturn because of Covid-19. Control plans to deal with socio-economic crises have changed the shape of investments that massively limit mobility (Sirkeci \& Yucesahin, 2020). Uncertainty in the future, such as this pandemic situation, has hit the economy in succession.

Figure 11 tabulates each increase in Covid-19. The pattern of poverty and GRDP per capita decreases because the logarithmic line is visible from top left to bottom right. Regarding natality, minimum wage, divorce, unemployment, and crime, the linearity line from top left to bottom right 
or positively distributed.

Theoretical support revealed by Nicola et al. (2020), where Covid-19 sparked fears of an economic recession and a prolonged crisis in the world. Travel restrictions, self-isolation and social distancing have reduced the work of people in all sectors of the economy. Indeed, health needs for medical supplies are proliferating. However, socio-economic aspects damage human survival.
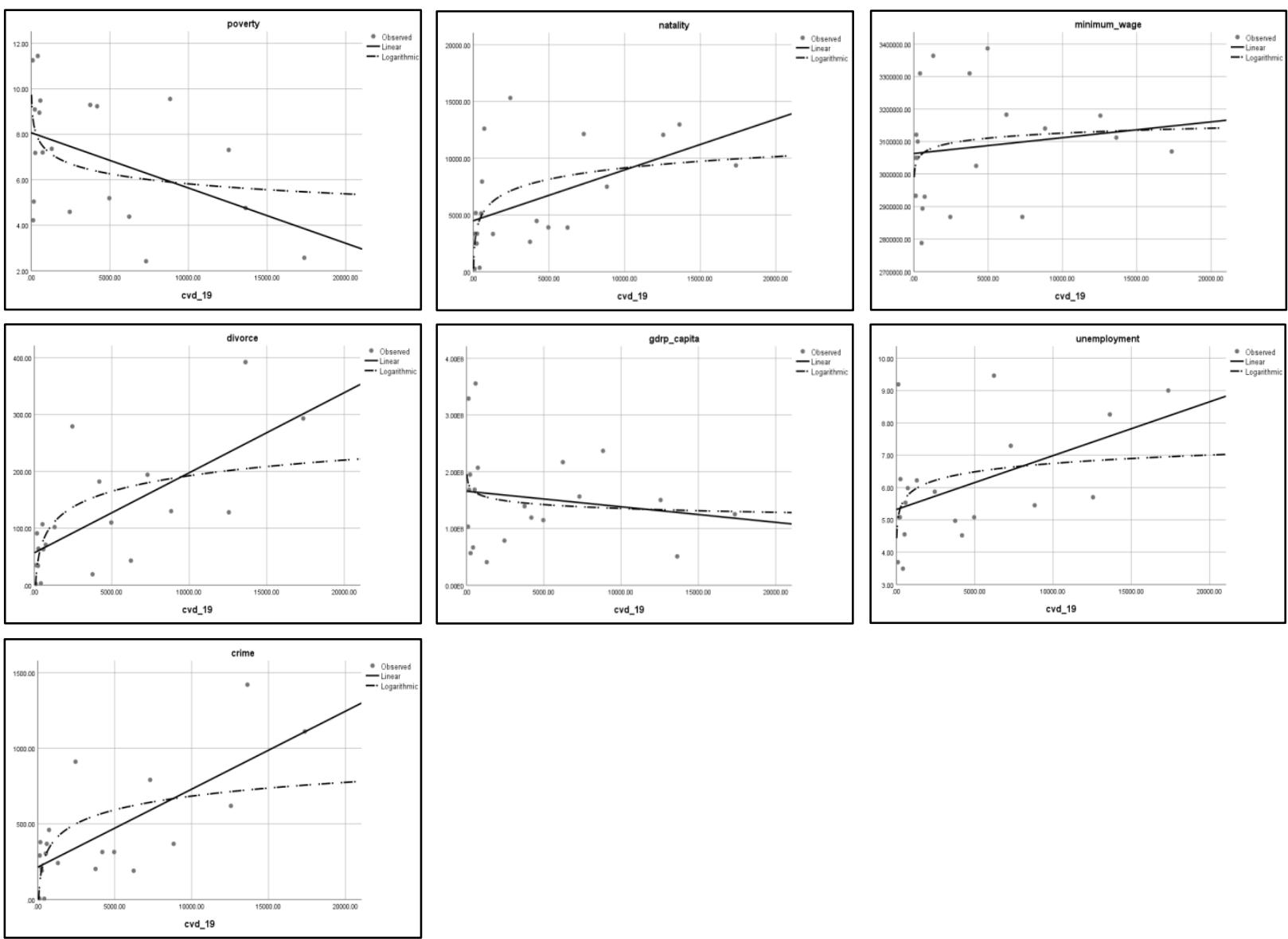

Source: calculation using SPSS

Figure 11. Linearity of Covid-19 Spread Points

It also highlighted logical arguments in South Asia. The trade sectors experienced major disruptions and headed for an economic crisis that could no longer expected. Although Southeast Asia has imposed strict lockdowns, it lacks the living space, health facilities, protection systems and sanitation that are no better than the Americas and Europe. Besides the large number of deaths, the risks and consequences that arise are macroeconomic instability, fiscal deficits, poverty, and excessive monetary burdens. Social harmonization broken and tensions are on the rise. Turbulence strengthens inequality between those with upper middle income and lower-class people (Rasul et al., 2021). The worst possibility in Southeast Asia is not to last long to face Covid-19 because the social and economic costs are very unequal.

In several low-income countries, such as Nigeria, Ethiopia, Uganda, and Malawi, the global economic contraction also affects and has implications for children and households. Josephson et al. (2021) and Martin et al. (2020) notes that this actually exacerbates the losses for those unable to access basic food and medicine. They confirm food insecurity to be a vital problem, and the government needs to change its policies and policies to expect further waves. 


\section{CONCLUSIONS AND SUGGESTION}

The point of this research is to identify the socio-economic transformation as the impact of Covid-19 in East Kalimantan Province. In reality, in two periods using cross-section, we conclude that Covid-19 positively correlated with minimum wages, unemployment, and crime. Regarding poverty and GRDP per capita, Covid-19 has a negative correlation. Covid-19, where empirical findings proved to positively correlated also caused the increase in birth rates and divorce cases. Thus, only three hypotheses accepted, while four of the seven hypotheses offered rejected.

The limitation of this study lies in the time-series, so it needs to be added to make it more varied. Future researchers, need to consider data and analysis models. The presentation of the data will interest, if they also compared it between before and after a phenomenon such as Covid-19. Synergy for the long term also prioritizes indirect effects.

In the long term, practical and theoretical contributions will certainly be an evaluation material for policy-makers, such as the government. Decision making requires a mature academic process, for example, through empirical findings.

\section{ACKNOWLEDGEMENT}

The authors would like to thank the reviewers at Jurnal Pendidikan Ekonomi \& Bisnis (JPEB) for their professional feedback. We also appreciate the research collaboration that has involved the two institutions.

\section{REFERENCES}

Afifah, Q.A. (2021). Analysis of the impact of the Covid-19 pandemic on family harmony: Case studies on family with and without people with special needs. Indonesian Journal of Community and Special Needs Education, 1(2), 87-92.

Ahmad, M., Khan, Y.A., Jiang, C., Kazmi, S.J., \& Abbas, S.Z. (2020). The impact of COVID-19 on unemployment rate: An intelligent based unemployment rate prediction in selected countries of Europe. International Journal of Finance \& Economics, 36(1), 1-16. https://doi.org/10.1002/ijfe.2434

Al Wahaibi, A., Al-Maani, A., Alyaquobi, F., Al Harthy, K., Al-Jardani, A., Al Rawahi, B., \& Al-Abri, S. (2021). Effects of COVID-19 on mortality: A 5-year population-based study in Oman. International Journal of Infectious Diseases, 104, 102-107. https://doi.org/10.1016/j.ijid.2020.12.054

Anser, M.K., Yousaf, Z., Nassani, A.A., Alotaibi, S.M., Kabbani, A., \& Zaman, K. (2020). Dynamic linkages between poverty, inequality, crime, and social expenditures in a panel of 16 countries: two-step GMM estimates. Economic Structures, 9(43), 1-25. https://doi.org/10.1186/s40008-020-00220-6

Aspachs, O., Durante, R., Graziano, A., Mestres, J., Reynal-Querol, M., \& Montalvo, J.G. (2021). Tracking the impact of COVID-19 on economic inequality at high frequency. PloS One, 16(3), e0249121. https://doi.org/10.1371/journal.pone.0249121

Azhari, A., Kamaruddin, K., Marzuki, M., \& Dewi, R. (2020). Do school accreditation, education budget, and teacher's competence matter for graduate's quality?. Jurnal Pendidikan Ekonomi dan Bisnis, 9(1), 01-08. https://doi.org/10.21009/JPEB.009.1.1

BPS. (2021). Survei perilaku masyarakat pada masa pandemi COVID-19 (Survey of community behavior during the COVID-19 pandemic). Retrieved from https://covid-19.bps.go.id/

BPS - East Kalimantan Province. (2021). Kalimantan Timur Province in figures 2021. Samarinda: Suvi Sejahtera.

Brata, A.G. (2021). The influence of colonial railways on Java economic geography. Theoretical and Empirical Researches in Urban Management, 16(2), 39-54. 
Day, M.V., \& Fiske, S.T. (2017). Movin' on up? how perceptions of social mobility affect our willingness to defend the system. Social Psychological and Personality Science, 8(3), 267274. https://doi.org/10.1177/1948550616678454

De Rose, A.F., Mantica, G., Ambrosini, F., Malinaric, R., Balzarini, F., Banchero, R., \& Terrone, C. (2021). COVID-19 impact on birth rates: First data from Metropolitan City of Genoa, Northern Italy. International Journal of Impotence Research, 1-2. https://doi.org/10.1038/s41443-021-00434-7

Estupinan, X., Gupta, S., Sharma, M., \& Birla, B. (2020). Impact of COVID-19 pandemic on labour supply, wages and gross value added in India. The Indian Economic Journal, 68(4), 572-592. https://doi.org/10.1177/0019466221999143

Finch, W.H., \& Hernández Finch, M.E. (2020). Poverty and Covid-19: Rates of incidence and deaths in the United States during the first 10 weeks of the pandemic. Frontiers in Sociology, 5(47), 1-10. https://doi.org/10.3389/fsoc.2020.00047

Fuadi, T.M., \& Irdalisa, I. (2020). Covid 19: Antara angka kematian dan angka kelahiran (Covid 19: Between the death rate and the birth rate). Jurnal Sosiologi Agama Indonesia, 1(3), 199-211. https://doi.org/10.22373/jsai.v1i3.767

Japan Official Development Assistance. (2021). Kemitraan setengah abad: Bantuan ODA Jepang di Indonesia (Half-century partnership: Japan's ODA assistance in Indonesia). Proyek ODA di setiap Provinsi. japan.go.jp/oda/id/provinces/odaprojects_map_kaltim.htm https://www.id.emb-

Josephson, A., Kilic, T., \& Michler, J.D. (2021). Socioeconomic impacts of COVID-19 in low-income countries. Nature Human Behaviour, 5(5), 557-565. https://doi.org/10.1038/s41562-02101096-7

Lebow, J.L. (2020). The challenges of COVID-19 for divorcing and post-divorce families. Family Process, 59(3), 967-973. https://doi.org/10.1111/famp.12574

Lee, B.Y., Brown, S.T., Bailey, R.R., Zimmerman, R.K., Potter, M.A., McGlone, S.M., Cooley, P.C., Grefenstette, J.J., Zimmer, S.M., Wheaton, W.D., Quinn, S.C., Voorhees, R.E., \& Burke, D.S. (2011). The benefits to all of ensuring equal and timely access to influenza vaccines in poor communities. Health Affairs, 30(6), 1141-1150. https://doi.org/10.1377/hlthaff.2010.0778

Manning, W.D., \& Payne, K.K. (2021). Marriage and divorce decline during the COVID-19 pandemic: A case study of five states. Socius: Sociological Research for a Dynamic World, 7, 1-3. https://doi.org/10.1177/23780231211006976

Mardisetosa, B., Khusaini, K., \& Gumelar Widia Asmoro. (2020). Personality, gender, culture, and entrepreneurial intentions of undergraduate student: Binary Logistic regression . Jurnal Pendidikan Ekonomi dan Bisnis, 8(2), 127-142. https://doi.org/10.21009/JPEB.008.2.5

Martin, A., Markhvida, M., Hallegatte, S., \& Walsh, B. (2020). Socio-economic impacts of Covid-19 on household consumption and poverty. Economics of Disasters and Climate Change, 4, 453479. https://doi.org/10.1007/s41885-020-00070-3

Martin, A., Markhvida, M., Hallegatte, S., \& Walsh, B. (2020). Socio-economic impacts of COVID-19 on household consumption and poverty. Economics of Disasters and Climate Change, 4, 453479. https://doi.org/10.1007/s41885-020-00070-3

Martinho, V.J. (2021). Impact of Covid-19 on the convergence of GDP per capita in OECD countries. Regional Science Policy \& Practice, 1-18. https://doi.org/10.1111/rsp3.12435

Mofijur, M., Fattah, I.M., Alam, M.A., Islam, A.B., Ong, H.C., Rahman, S.M., Najafi, G., Ahmed, S.F., Uddin, M.A., \& Mahlia, T.M. (2021). Impact of COVID-19 on the social, economic, environmental and energy domains: Lessons learnt from a global pandemic. Sustainable Production and Consumption, 26, 343-359. https://doi.org/10.1016/j.spc.2020.10.016

Nicola, M., Alsafi, Z., Sohrabi, C., Kerwan, A., Al-Jabir, A., Iosifidis, C., Agha, M., \& Agha, R. (2020). 
The socio-economic implications of the coronavirus pandemic (COVID-19): a review. International Journal of Surgery, 78, 185-193. https://doi.org/10.1016/j.ijsu.2020.04.018

Nivette, A.E., Zahnow, R., Aguilar, R., Ahven, A., Amram, S., Ariel, B., Burbano, M., Astolfi, R., Baier, D., Bark, H.M., Beijers, J., Bergman, M., Breetzke, G., Concha-Eastman, I.A., CurtisHam, S., Davenport, R., Díaz, C., Fleitas, D., Gerell, M., Jang, K. H., ... Eisner, M. P. (2021). A global analysis of the impact of COVID-19 stay-at-home restrictions on crime. Nature Human Behaviour, 5(7), 868-877. https://doi.org/10.1038/s41562-021-01139-z

Nghiem, N., \& Wilson, N. (2021). Potential impact of COVID-19 related unemployment on increased cardiovascular disease in a high-income country: Modeling health loss, cost and equity. PloS one, 16(5), e0246053. https://doi.org/10.1371/journal.pone.0246053

Office of Communication and Information - East Kalimantan Province. (2021). Press release 105: Covid-19. Retrieved from https://covid19.kaltimprov.go.id/storages/file/PR\%20105\%20tanggal\%2030\%20Juni\%20puk ul\%2012.00.pdf

Prawoto, N., Purnomo, E.P., \& Zahra, A.A. (2020). The impacts of Covid-19 pandemic on socioeconomic mobility in Indonesia. International Journal of Economics and Business Administration, 8(3), 57-71. https://doi.org/10.35808/ijeba/486

Rahman, I.U., Jian, D., Junrong, L., \& Shafi, M. (2021). Socio-economic status, resilience, and vulnerability of households under COVID-19: Case of village-level data in Sichuan province. PLoS ONE, 16(4), e0249270. https://doi.org/10.1371/journal.pone.0249270

Rasul, G., Nepal, A.K., Hussain, A., Maharjan, A., Joshi, S., Lama, A., Gurung, P., Ahmad, F., Mishra, A., \& Sharma, E. (2021). Socio-economic implications of COVID-19 pandemic in South Asia: emerging risks and growing challenges. Frontiers in Sociology, 6, 629693. https://doi.org/10.3389/fsoc.2021.629693

Rebhun, U. (2021). Inter-country variations in COVID-19 incidence from a social science perspective. Migration Letters, 18(4), 413-423. https://doi.org/10.33182/ml.v18i4.1254

Rufat, S., Tate, E., Emrich, C.T., \& Antolini, F. (2019). How valid are social vulnerability models?. Annals of the American Association of Geographers, 109(4),

Shimamoto, K. (2019). Determining factors of waste management in Japan. Theoretical and Empirical Researches in Urban Management, 14(3), 62-76.

Sirkeci, I., \& Yucesahin, M. M. (2020). Coronavirus and migration: Analysis of human mobility and the spread of Covid-19. Migration Letters, 17(2), 379-398. https://doi.org/10.33182/ml.v17i2.935

Su, C-W., Dai, Ke., Ullah, S., \& Andlib, Z. (2021). COVID-19 pandemic and unemployment dynamics in European economies. Economic Research-Ekonomska Istraživanja, 1-14. https://doi.org/10.1080/1331677X.2021.1912627

Suparjo, S., Darma, S., Kurniadin, N., Kasuma, J., Priyagus, P., Darma, D.C., \& Haryadi, H. (2021). Indonesia's new sdgs agenda for green growth - emphasis in the energy sector. International Journal of Energy Economics and Policy, 11(3), 395-402. https://doi.org/10.32479/ijeep.11091

Supriatna, E. (2020). Socio-economic impacts of the Covid-19 pandemic: The case of Bandung City. Journal of Governance, 5(1), 61-70. http://dx.doi.org/10.31506/jog.v5i1.8041

Surni, S., Nendissa, D.R., Wahib, M.A., Astuti, M.H., Arimbawa, P., Miar, M., Kapa, M.M., \& Elbaar, E.F. (2021). Socio-economic impact of the Covid-19 pandemic: Empirical study on the supply of chicken meat in Indonesia. AIMS Agriculture and Food, 6(1), 65-81. http://dx.doi.org/10.3934/agrfood.2021005

Suryahadi, A., Izzati, R.A., \& Suryadarma, D. (2020) Estimating the impact of Covid-19 on poverty in Indonesia. Bulletin of Indonesian Economic Studies, 56(2), 175-192. https://doi.org/10.1080/00074918.2020.1779390 
Wang, Q., \& Taylor, J. E. (2016). Patterns and limitations of urban human mobility resilience under the influence of multiple types of natural disaster. PLoS ONE, 11(1), e0147299. https://10.1371/journal.pone.0147299

Yang, M., Chen, Z., Zhou, M., Liang, X., \& Bai, Z. (2021). The impact of COVID-19 on crime: A spatial temporal analysis in Chicago. ISPRS International Journal of Geo-Information, 10(3), 152. https://doi.org/10.3390/ijgi10030152

Yijo, S., Asnawati, A., Darma, S., Achmad, G.N., Arizandi, M.A., Hidayati, T. \& Darma, D.C. (2021). Social experiments on problems from tomato farmers during Covid-19 - Indonesia case. SAR Journal - Science and Research, 4(1), 7-13. https://doi.org/10.18421/SAR41-02

Zarghami, S.A., \& Dumrak, J. (2021). A system dynamics model for social vulnerability to natural disasters: disaster risk assessment of an Australian city. International Journal of Disaster Risk Reduction, 60, 102258. https://doi.org/10.1016/j.ijdrr.2021.102258

Zarkasyi, M.R., Kurniawan, D.A., \& Darma, D.C. (2021). Urgensity of "halal tourism": religiosity, awareness, and interest from stakeholders. Journal of Environmental Management and Tourism, 4(52), 968-976. https://doi.org/10.14505/jemt.v12.4(52).11 